\title{
Profile of Antibiotic Resistant Bacteria Isolated from Slaughterhouse Effluents of Etoudi-Yaounde and Its Receiving Waterbody
}

\author{
Merveille Tamema Masse ${ }^{1}$, Romuald Jacques Samba Aloys ${ }^{1}$, \\ Brunelle Tchakounte Betbui ${ }^{1}$, Blaise Pascal Bougnom ${ }^{1}$ \\ ${ }^{1}$ Department of Microbiology, Faculty of Science, University of Yaoundé I, P.O. Box 812 Yaounde, Cameroon
}

Corresponding Author: Blaise Pascal Bougnom

\begin{abstract}
The Profile of antibiotic resistant bacteria isolated from slaughterhouse effluents of Etoudi-Yaounde, and its receiving waterbody (River Ako'o) were investigated. Wastewater samples were collected from abattoir outlet and along the river (pond, mid river and out-river). Resistance to amoxicillin, tetracycline, ciprofloxacin, sulfamethoxazole / trimethoprim, cefixime and kanamycin were determined. Resistance to amoxicillin was the highest $(96.3 \%)$, followed by sulfamethoxazole / trimethoprim $(85.1 \%)$, kanamycin $(81.5 \%)$, cefixime $(81.3 \%)$, tetracycline $(80.9 \%)$ and ciprofloxacin $(73.6 \%)$. Bacterial resistance was higher in October, compared to March and December. Higher resistance ratios were observed downstream at out-river (77.9 \%). Enterobacteria constituted $80 \%$ of the isolates. Escherichia coli, Salmonella spp., Klebsiella spp., Shigella spp., Staphylococcus spp. and Streptococcus spp. were the identified drug resistant bacteria, Escherichia coli was more prevalent $(30.7 \%)$. All isolates were multi-resistant antibiotic resistant bacteria and some presented resistance to third generation cephalosporin. Wastewater from Etoudi-abattoir is a serious vector of the spread of bacterial drug resistance, thus, strategies towards hygiene and sanitation of the slaughterhouse and its effluents should be implemented.
\end{abstract}

Keywords: Antibiotic resistance, slaughterhouse wastewater, public health

\section{INTRODUCTION}

The use of any therapeutic agent is compromised by the potential development of tolerance or resistance to that compound from the time it is first employed. This threatens their therapeutic accomplishment and jeopardizes the positive outcomes of critically ill patients (Munita and Arias, 2016). Infections caused by drug resistant organisms are associated with excess mortality, prolonged hospital stays, and increased costs (FAO, 2016). The United Nations General Assembly (UNGA) has recognised Antimicrobial resistance (AMR) as the fourth global health issue. AMR is projected to cause ten million deaths annually worldwide for 4,150,000 in Africa by 2050 (CDDEP, 2015). The most striking example, and probably the costliest in terms of morbidity and mortality concerns bacteria (Davies and Davies, 2010). According to the United States Centre for Disease Control and Prevention (CDC), antibiotic-resistant bacteria (ARB) lead to the death of about 23,000 people annually in USA and 25,000 deaths in Europe (Munita and Arias, 2016). In fact, antibiotic resistance is relentless, getting more prevalent widely disseminated and few new antibiotics are in development (Appelbaum, 2012). Overuse and improper use of antibiotics are recognized as key drivers of the emergence and spread of bacterial resistance (BR) (FAO, 2016) though antibiotic-resistant bacteria also 
predominantly arise from environmental pollution (Holmes et al., 2015). Bacteria may develop resistance due to exposure to sub-lethal levels of antibiotics in their surroundings, or alternatively, bacteria may directly acquire resistance mechanisms from other bacteria via DNA transfer (Lekshmi et al., 2017).

It is projected that two thirds of antibiotic use will be for animal production (Van Boeckel et al., 2015). Antibiotics are used to control, prevent and treat infection, to enhance animal growth and feed efficiency (Darwish et al., 2013). Unfortunately, their use especially in African countries remains largely unregulated (Mehrabi et al., 2020). Uncontrolled use of antibiotics in animals is to respond to the continuous drive to increase meat production for protein needs of the ever-increasing population (Onuoha et al.,2016). These antibiotics are the same as or surrogates of antibiotics used in human therapeutic practice (Mehrabi et al., 2020). Commonly used medications in the Farnorth region of Cameroon (procaine penicillin $\mathrm{G}$ and oxytetracycline) are used in a manner inconsistent with the recommended dosage, frequency, duration, and withdrawal period by $98 \%$ of pastoralists (Vougat et al., 2017). About 20 to $80 \%$ of these antibiotics administered to animals are excreted either as the parent compound or as metabolites in urine and faeces, which later get into sewage or wastewater (Agga et al., 2019). Pollution caused by these proceedings can be transmitted directly or indirectly to human via diverse pathways of which slaughterhouses and their environment in part due to the enormous quantity of wastewater it generates. This is a serious concern in LMICs, where slaughterhouse wastewater is released untreated into the environment and it flows downstream into nearby water bodies (Zanga et al., 2016).

Slaughterhouse and their environments have been related to ARB (Zhang et al., 2009; Lekshmi et al., 2017; Rousham et al., 2018). Also, all the rivers in the Mfoundi watershed in the Yaoundé are subject to organic pollution of anthropogenic origin (Zébazé et al., 2005; Onana, 2009; Zanga et al., 2017). Nevertheless, investigation into resistance pattern to common antibiotics in slaughterhouse wastewater is scarce in Cameroon. Therefore, assessing the occurrence of drug resistant bacteria from slaughterhouse wastewater is a public health concern that should be addressed. we designed our study to assess the dynamic of ARB in wastewater originating from Etoudi-abattoir and its receiving waterbody.

\section{MATERIAL AND METHODS Site description}

Yaounde is the capital of Cameroon with a surface area of $180 \mathrm{~km}^{2}$ and a population of about 2.8 million inhabitants. It is located at $3^{\circ} 52^{\prime} \mathrm{N}$ and $11^{\circ} 32^{\prime} \mathrm{E}$. The average annual temperature is $23.5^{\circ} \mathrm{C}$ and a rainfall of $1650 \mathrm{~mm}$ per year. Etoudi abattoir is the major abattoir of Yaounde. This abattoir has a rate of 40,000 to 90,000 beefs slaughtered per year, spilling up to 6000 cubic metres of effluents each year. Waste from slaughtering process is usually washed to the drainage system into the right shore of the river Ako'o without prior treatment. The watershed of the Ako'o river covers an area of $26.5 \mathrm{~km}^{2}$ and extends into the northern part of the Department of Mfoundi crossing the districts of Yaounde 1 and 2 .

\section{Sample collection}

A total of 108 samples were collected at four different sites: Slaughterhouse outlet; Point of discharge (EA); Upstream of the river at about 400 meters from the point of discharge (P); Mid Ako'o River at about $2 \mathrm{Km}$ from the point of discharge of slaughterhouse effluents (RA), and at about $4 \mathrm{~km}$ from Slaughterhouse effluents discharges point (RB). Sampling was conducted three times over a period of six months; from October 2019 to March 2020. After collection, the samples were protected from sunlight by 
putting them in an ice box and transported to the laboratory in a refrigerated cooler prior to analysis.

\section{Isolation and enumeration of total resistant bacteria}

Antibiotic resistant bacteria were isolated on Luria Bertani agar supplemented with the following antibiotic concentrations: $16 \mu \mathrm{g} / \mathrm{ml}$ of Tetracycline (TET, Sigma), 4 $\mu \mathrm{g} / \mathrm{ml}$ of Ciprofloxacin (CIP, Sigma), 64 $\mu \mathrm{g} / \mathrm{ml}$, (8: 1) Sulfamethoxazole / Trimethoprim (Sul / Trm, Sigma), $5 \mu \mathrm{g} / \mathrm{ml}$ of Cefixime, $32 \mu \mathrm{g} / \mathrm{ml}$ of Amoxicillin (AMC, Sigma), $4 \mu \mathrm{g} / \mathrm{ml}$ of Kanamycin. The plates were incubated at $37^{\circ} \mathrm{C}$ for $48 \mathrm{hrs}$. The selected antibiotic concentrations were based on previous studies (Watkinson et al., 2007). All the procedures were done in triplicate. Grown colonies were counted and the percentage of resistance for each antibiotic corresponding to the ratio of CFU mL-1 on the culture medium with and without antibiotic (Novo and Manaia, 2010) was reported. Colonies with different morphologies were observed on the plates and streaked out on Luria Bertani agar for purification and isolation. Colonies were then stored at $4^{\circ} \mathrm{C}$ in Muller Hinton broth supplemented with glycerol at $15 \%$ for further identification.

\section{Identification of antibiotic resistant bacteria}

Antibiotic resistant bacteria were identified by comparing their colony morphology, Gram staining, catalase test, coagulase test and growth on specific media. Gram negative bacteria were seeded on deoxycholate agar (for isolation of Enterobacteria), Eosin methylene blue agar (for isolation of Escherichia coli) and Salmonella-Shigella agar (for isolation of Salmonella spp) while Gram positive bacteria were separated with catalase test and coagulase test and were seeded on bile esculin agar (for isolation of Streptococcus spp.).

\section{RESULTS AND DISCUSSION}

Microbiological analysis revealed that abattoir wastewater samples were highly contaminated by antibiotic resistant bacteria. Highest resistance ratio was obtained with amoxicillin (96.3\%), followed by sulfamethoxazole / trimethoprim $(85.1 \%)$; while lowest resistance ratio was obtained with ciprofloxacin $(73.6 \%)$ (Table $1)$.

Table 1: Resistance ratio (\%) of bacteria to different antibiotics

\begin{tabular}{|l|l|}
\hline Antibiotics & Mean resistance ratio \\
\hline Amoxicillin & $96.3 \pm 6.42^{\mathrm{a}}$ \\
\hline Bactrim & $85.1 \pm 10.4^{\mathrm{b}}$ \\
\hline Kanamycin & $81.5 \pm 13.1^{\mathrm{bc}}$ \\
\hline Cefixime & $81.2 \pm 14.3^{\mathrm{bc}}$ \\
\hline Tetracycline & $80.9 \pm 10.5^{\mathrm{bc}}$ \\
\hline Ciprofloxacin & $73.6 \pm 15.5^{\mathrm{c}}$ \\
\hline
\end{tabular}

Values following with the same letter do not significantly differ, SNK test $(P<0.05)$.

The microbiological analysis revealed that abattoir wastewater samples were highly contaminated by antibiotic resistant bacteria. This can be attributed to the indiscrete slaughtering practices, in fact there are no quality guidelines regarding such proceedings in the country added to this is the poor state of health of the slaughtered animals (Fonteh et al., 2016).

Overall, amoxicillin was reported to be the least effective antibiotic with an average percentage resistance ratio of $96.3 \%$. Decrease in the sensitivity of bacteria to Penicillins is a consequence of their frequent use as first-line antibiotics against all kinds of infections both in human and animal husbandry (Novo and Manaia, 2010). Moreover, Beta lactams are the most imported antibiotics for animal use in Cameroon (Mouiche et al., 2020). High Resistance ratios to aminoglycosides represented by kanamycin $(81.5 \%)$, is a serious public health issue because kanamycin is a broad-spectrum antibiotic of last generation. Resistance ratio with Tetracycline of $80.9 \%$ was greater than that reported by Nova and Manaia, (2013) of $1.88 \%$ in Portugal. This difference could be explained by the fact that in Cameroon, in addition to self-medication, Tetracyclines 
are among the most prescribed antibiotics in animal and human medicine for the treatment of a large number of infections (Fonteh et al., 2016; Vougat et al., 2017). On the other hand, our results revealed that bacteria showed lower resistance ratios with ciprofloxacin $(73.6 \%)$ compared to other antibiotics tested. In fact, quinolones are rarely used in veterinary medicine in Cameroon compared to other antibiotics (Mouiche et al., 2020). Moreover, mechanisms of resistance to these antibiotics described are essentially chromosomal (have a probability of very weak appearance: occurs on average every 106 to 109 divisions), though recently described mechanisms such as active efflux emerge but still confer low levels of resistance to this family (Muylaert et al., 2013). However, resistance ratio to ciprofloxacin $(73.6 \%)$ is greater than that reported by other authors in past studies (Nova and Manaia, 2013), this is a serious public health issue because ciprofloxacin is a broad-spectrum antibiotic of last generation thought to be very effective against various bacterial infections such as that to Salmonella (Iroha et al., 2016).

Overall, resistance ratios to all tested antibiotics were higher than those obtained by Nagulapally et al. (2009); Akiyama et al. (2010); Sibhat et al. (2011); Ben Said et al. (2015); Iroha et al. (2016) and Omoregbe (2017). From 2014-2019, the percentage of antibiotic importation and use in animal increased by $104 \%$ in Cameroon. Moreover, 217.67 tonnes of antimicrobials were imported for use in food-producing animals over the 6-year period (2014-2019) with an average of $36.28 \pm 10.11$ tonnes per year. The most imported antibiotics for use in pigs and cattle being Tetracyclines, Aminoglycosides, Beta-lactams, Sulfonamides and Quinolones (Mouiche et al., 2020). This abusive use arises because in African countries, the use and control of antibiotics remains largely unregulated (Mehrabi et al. 2020).
Higher resistance ratios were observed during October (86.3\%) compared to March and December (Table 2).

Table 2: Resistance ratio (\%) of bacteria at different months

\begin{tabular}{|l|l|}
\hline Sampling dates & Mean resistance ratio \\
\hline October & $86.3 \pm 8.16^{\mathrm{a}}$ \\
\hline December & $84.6 \pm 11.9^{\mathrm{ab}}$ \\
\hline March & $83.7 \pm 13.4^{\mathrm{ab}}$ \\
\hline
\end{tabular}

Values following with the same letter do not significantly differ, SNK test $(P<0.05)$.

Resistance ratios were higher during October compared to December and March. This trend has also been reported by Ham et al. (2012) as they found increased multiple resistant bacteria in September and October during rainy seasons in Tama river, in Japan, and by Aliyu (2016) who reported higher levels of bacteria in river LavunBida, in Nigeria during rainy seasons. In fact, the River Ako'o is surrounded by the highly urbanized Yaounde Metropolitan area, and as rain fall become frequent, more pollutants (municipal, agricultural land runoff and stagnant ponds) find their way into the river through drainage and flooding combined to sewer overflows being the main sources of faecal contamination (Aliyu, 2016). This could explain the greater prevalence of ARB during rainy season.

Antibiotic resistance ratios were higher at the pond $(86.3 \%)$ while lowest downstream at out-river (77.9\%) (Table 3).

Table 3: Comparison of resistance ratio (\%) of bacteria at sampling points

\begin{tabular}{|l|l|}
\hline Sampling points & Mean resistance ratio \\
\hline Ponds & $86.3 \pm 10.79^{\mathrm{a}}$ \\
\hline Mid river & $84.6 \pm 15.1^{\mathrm{ab}}$ \\
\hline Abattoir outlet & $83.7 \pm 12.5^{\mathrm{ab}}$ \\
\hline Out river & $77.9 \pm 15.0^{\mathrm{b}}$ \\
\hline
\end{tabular}

Values with the same letter do not significantly differ, SNK test $(P<0.05)$.

Higher resistance ratio $(86.2 \%)$ at the pond can be attributed to the accumulation of abattoir drains and waste at that point due to poor drainage system of the area. Resistance ratio decreased progressively downstream to $(77.9 \%)$ at outriver. As wastewaters flows downstream, diffusion and self-purification enhance the decrease in concentration of organisms by some physical and chemical action such as 
flowing, dilution, deposition and adsorption (Tian et al., 2011). Despite these phenomena, resistance ratios at these points downstream were quite high. This situation of high levels of bacterial resistance downstream at a point where the population use this water for diverse means including drinking, bathing, washing, rearing and plants irrigation is awfully alarming because these resistant bacteria can be transferred to human and animals via direct or indirect means (FAO, 2016).

In this study a total of forty-six drug resistant bacteria were isolated, amongst, Escherichia coli, Salmonella spp, Klebsiella spp, Shigella spp, Staphylococcus spp and Streptococcus spp. (Table 4).

Table 4: Frequency of antibiotic resistant bacteria isolated
from wastewater samples.
\begin{tabular}{|l|l|}
\hline Resistant bacteria & Frequency \\
\hline E. coli & $30.7 \%$ \\
\hline Shigella spp & $19.2 \%$ \\
\hline Salmonella spp & $19.2 \%$ \\
\hline Klebsiella spp & $11.5 \%$ \\
\hline Staphlococcus aureus & $19.2 \%$ \\
\hline Streptococcus spp & $2.17 \%$ \\
\hline Total & $100 \%$ \\
\hline
\end{tabular}

The isolated antibiotic resistant bacteria were present in all the sampling sites and multi-resistant, including resistance to the third-generation cephalosporin cefixime. (Table 5).

Table 5: Resistance pattern of antibiotic-resistant bacteria in wastewater

\begin{tabular}{|c|c|c|c|c|c|c|c|}
\hline \multirow[t]{2}{*}{ Isolates } & \multirow[t]{2}{*}{ Total number (\%) } & \multicolumn{6}{|c|}{ Number of antibiotic resistant bacteria (\%) } \\
\hline & & $\mathrm{AMC}$ & TET & CEF & CIP & KAN & BAC \\
\hline E. coli & $30.8(8 / 27)$ & $38.1(8 / 21)$ & $16.7(2 / 12)$ & $29.4(5 / 17)$ & $18.8(3 / 16)$ & $26.7(4 / 15)$ & $42.1(8 / 19)$ \\
\hline Shigella & $19.2(5 / 27)$ & $14.3(3 / 21)$ & $16.7(2 / 12)$ & $29.4(5 / 17)$ & $18.8(3 / 16)$ & $26.7(4 / 15)$ & $26.3(5 / 19)$ \\
\hline Salmonella & $19.2(5 / 27)$ & $14.3(3 / 21)$ & $16.7(2 / 12)$ & $0(0 / 17)$ & $31.3(5 / 16)$ & $6.7(1 / 15)$ & $5.3(1 / 19)$ \\
\hline Klebsiella & $11.5(3 / 27)$ & $4.8(1 / 21)$ & $25(3 / 12)$ & $11.8(2 / 17)$ & $12.5(2 / 16)$ & $6.7(1 / 15)$ & $5.3(1 / 19)$ \\
\hline S. aureus & $19.2(5 / 27)$ & $23.8(5 / 21)$ & $25(3 / 12)$ & $29.4(5 / 17)$ & $18.8(3 / 16)$ & $26.7(4 / 15)$ & $15.8(3 / 19)$ \\
\hline Streptococcus & $2.2(1 / 27)$ & $4.8(1 / 21)$ & $0(0 / 12)$ & $0(0 / 17)$ & $0 / 16)$ & $(1 / 15)$ & $5.3(1 / 19)$ \\
\hline Total & 27 & 21 & 12 & 17 & 16 & 15 & 19 \\
\hline
\end{tabular}

In this study we identified five major bacteria genera among isolates predominated by Enterobacteria. Bacteria identified from abattoir wastewater were $E$. coli, Salmonella spp, Shigella spp, Staphylococcus aureus, and Streptococcus spp.

E. coli had the highest prevalence rate of $30.8 \%$ from slaughterhouse effluents. These results are similar to those of Iroha et al., (2016) who isolated $33.3 \%$ of E. coli from Ogbete abattoir effluent in Enugu State, Nigeria. The presence of E. coli in water suggests faecal contamination. This could result in outbreaks of $E$. coli infections since this bacterium is part of the normal flora of human and animal gut (Nafarnda et al., 2012). In general, the development of drug resistant E. coli isolates and other gram-negative bacteria can be linked to various aspects including the practice of indiscriminate use of antibiotics in food producing animals (Omoregbe et al., 2017).
The presence of Salmonella spp. $(19.23 \%)$ in all the samples analysed is not surprising since Salmonella has been reported to be an environmentally persistent pathogen capable of surviving and proliferating in diverse environments (Mehrabi et al. 2020). The prevalence rate of Salmonella obtained in this study is however lower than those reported by in Buea, Cameroon and in Nigeria (Akoachéré et al., (2009); Onuoha et al., (2016); Iroha et al., (2016)). This may be a result of the use of last generation cephalosporins and fluoroquinolones for treatment of Salmonella infections (Iroha et al., 2016). Presence of Shigella (19.2\%) makes it reasonable to suggest that contamination of these effluents could come from abattoir workers since humans are possible Shigella hosts.

Further, greater abundance of Staphylococcus aureus at all sampling points could be attributed to contamination from the hides of animals, hands and skin of abattoir workers, since $S$. aureus is a normal 
flora of the skin of healthy mammals and proper hygiene practices are not adhered to during slaughter process. High levels of $S$. aureus resistant $(19.2 \%)$ to antibiotics were in support to the findings of Iroha et al., (2016). They would therefore have acquired their resistance genes under the pressure of the permanent use of antibiotics on animals as growth factors or for the treatment of bacterial infections. Likewise, S. aureus isolates from Africa show a high degree of resistance to penicillin, tetracycline, and trimethoprim/ sulfamethoxazole, indicating the wide use of these drugs in African countries (CDDEP, 2015).

Bacteria isolates identified were multidrug resistant as their antibiotic resistance profiles showed that they were resistant to at least three classes of antibiotics. The presence of these pathogenic organisms suggests the presence of other opportunistic and pathogenic bacteria. Thus, the conclusion that the abattoir waste contains only these organisms cannot be drawn, since all bacterial isolates were not identified, the study was limited, and results were based only on the samples analysed. Uncharacterized strains made up $43.48 \%$ of the total isolates. This study demonstrated that bacterial isolates show resistance to antibiotics commonly used as feed additives (Tetracycline, Sulfamethoxazole/ Trimethoprim) or therapeutics (Penicillin, Ciprofloxacin, Kanamycin and Tetracycline (Mouiche et al., 2020). In Cameroon, many abattoirs dispose their effluents directly into streams and rivers without any form of treatment and slaughtered animals are washed by the same waters (Fonteh et al., 2016). Therefore, the occurrence of high total bacteria counts and Enterobacteriaceae count in the effluent from these abattoirs represent a greater public health concern (Timilehin et al., 2016). Most of the bacteria isolates identified in this study have been implicated as pathogenic organisms (Timilehin et al., 2016) implying that the study area is associated as potential source of infectious outbreak.
Increasing the use of vaccines in food animals as alternatives to antibiotic drugs has received strong support. Available vaccines for food animals include those against the pathogens Salmonella enterica serovar Choleraesuis and $S$. enterica serovar Typhimurium (Mehrabi et al., 2020). Finally, improved sanitary conditions as well as the maintenance of biosecurity are important alternatives that could be adopted by workers instead of depending on antibiotic drugs for disease control and prevention. These would essentially serve as a means of preventing the entry and dissemination of ARB amongst animals.

\section{CONCLUSION}

Assessing the occurrence and dynamism of drug resistant bacteria in wastewater originating from Etoudi Abattoir, and its receiving waterbody, permitted to appreciate the variability of antibiotic resistant bacteria abundance from site to site and from one period to another. Spatial variation as well as seasons seemed to influence the abundance and dynamic of antibiotic resistance bacteria. Members of the family Enterobacteriaceae were the most prevalent among the isolated strains. The results obtained demonstrate the serious health issue represented by these waters for the populations coming into contact with these waters. Based on our results, Etoudi Abattoir is a serious vector for the spread of bacterial resistance. Therefore, it is very imperative for the abattoir effluents to be properly treated before being discharged into the environment.

\section{Acknowledgement: None}

\section{Conflict of Interest: None}

\section{Source of Funding: None}

Ethical Approval: Approved

\section{REFERENCES}

1. Agga G., Cook, K. L., Netthisinghe A., Gilfillen, R. A., Woosley P. B., and Sistani 
K. R. (2019). Persistence of antibiotic resistance genes in beef cattle backgrounding environment over two years after cessation of operation. PloS one. 14(2).19p.

2. Akoachere J., Tanih N., Ndip L. and Ndip R. (2009). Phenotypic characterization of Salmonella Typhimurium isolates from food-animals and abattoir drains in Buea, Cameroon. Journal of Health, Population and Nutrition. 27(5):612-618

3. Akiyama T. and Savin M. (2010). Populations of antibiotic-resistant conform bacteria change rapidly in a wastewater effluent dominated stream. The Science of the Total Environment.408:6192-6201.

4. Aliyu A. (2016). Bacteriological and physicochemical qualities of water and fish samples from river lavun, bida, niger state, Nigeria. Master thesis in microbiology. Ahmadu Bello University, Zaria Nigeria. $131 \mathrm{p}$.

5. Appelbaum P. and Beyond (2012). Potential for the Start of a Second Pre-antibiotic Era? Journal of Antimicrobial Chemotherapy. 67(9):2062-2068.

6. Ben-Said L., Klibi N., Lozano C., Dziri R., Ben-Slama K., Boudabous A., and Torres C. (2015). Diversity of enterococcal species and characterization of high-level aminoglycoside resistant enterococci of samples of wastewater and surface water in Tunisia. Science of The Total Environment. 30:11-17.

7. Cattoen (2015). Persistence du portage des bactéries multirésistantes après la réanimation. Réanimation. 24(3): 249-255.

8. CDDEP (Center for Disease Dynamics, Economics \& Policy) (2015) Washington D.C. ResistanceMap.

9. Darwish W. S. and Eldaly M. (2013). Antibiotic residues in food: the African scenario. Japanese Journal of Veterinary Research. 6(9): S13-S22.

10. Davies J. and Davies D. (2016). Origin and evolution of antibiotic resistance. Microbiology and molecular biology reviews. 74(3): 417-433

11. FAO (Food and Agriculture Organisation) (2016). Drivers, dynamics and epidemiology of antimicrobial resistance in animal production. Rome, Italy

12. Fonteh F., Kouam M., Zibi II M., Tjeega G. and Aidrou L. (2016). Wholesomeness of beef from cattle slaughtered in cameroon, central Africa. Journal of meat science and technology. 4(1): 18-24

13. Ham Y.-S., Kobori H., Kang J.-H., Matsuzaki T., Lino M., and Nomura $\mathrm{H}$. (2012).Distribution of antibiotic resistance in urban watershed in Japan. Environmental Pollution. 162:98-103.

14. Holmes A., Moore L., and Sundsfjord A. (2016). Understanding the mechanisms and drivers of antimicrobial resistance. Lancet. 387(10014):176-187.

15. Iroha, I., Eromonsele O., MosesI B., and Afiukwa F. (2016). In vitro antibiogram of multidrug resistant bacteria isolated from Ogbete abattoir effluent in Enugu State, Nigeria. International Research Journal of Public and Environmental Health. 3 (1): 1-6.

16. Lekshmi M., Parvathi A., Kumar S. and Varela M. (2017). The Food Production Environment and the Development of Antimicrobial Resistance in Human Pathogens of Animal Origin. Microorganisms. 5p.

17. Mehrabi Z., Gill M. and Wijk M. (2020). Livestock policy for sustainable development. Nature Food 1:160-165

18. Mouiche M.M., Moffo F. and Akoachere J. K. (2019). Antimicrobial resistance from a one health perspective in Cameroon: a systematic review and meta-analysis. Biomed central public health.19(1):1135.

19. Mouiche M. M. M., Moffo, F., Betsama, J. D. B., Mapiefou, N. P., Mbah, C. K., Mpouam, S. E., and Awah-Ndukum, J. (2020). Challenges of antimicrobial consumption surveillance in foodproducing animals in Sub-Saharan African countries: Patterns of antimicrobial imported in Cameroon from 2014 to 2019. Journal of Global Antimicrobial Resistance. 22:771778Nova and Manaia, (2013)

20. Munita J. M., and Arias C. A. (2016). Mechanisms of Antibiotic Resistance. Microbiology Spectrum.4(2):10.1128

21. Muylaert A. and Mainil J.G. (2013). Fluoroquinolones resistances: The current situation. Annales de Medecine Veterinaire. 157:15-26.

22. Nafarnda W. D., Ajayi I. E., Shawulu J. C., Kawe M. S., Omeiza G. K., Sani, N. A., and Tags S. Z. (2012). Bacteriological Quality of Abattoir Effluents Discharged into Water Bodies in Abuja, Nigeria. Veterinary Science.5p.57 
23. Nagulapally S. R., Ahmad A., Henry A., Marchin G. L., Zurek L., and Bhandari A. (2009). Occurrence of ciprofloxacin-, trimethoprim-sulfamethoxazole-, and vancomycin-resistant bacteria in a municipal wastewater treatment plant. Water environment research. 81(1):82-90;

24. Novo A., and Manaia C. (2010). Factors influencing antibiotic resistance burden in municipal wastewater treatment plants. Applied Microbiology Biotechnology 87: 1157-1166.

25. Omoregbe N. (2017). Antibiotic susceptibility and microbial analysis of Enterobacteriaceae from wastewater and sediments from abattoirs in Makurdi. Benue State. International Journal of Applied Microbiology and Biotechnology Research. 5:103-109

26. Onana F.M., (2009). Evaluation de la qualité des eaux du Mfoundi : Annalyses physicochimiques et structure de la communauté zooplanctonique. Mémoire de Diplôme d'Etudes Approfondies. Faculté des Sciences, Université de Yaoundé 1. 64 p

27. Onuoha S., Onyebuchi O., Aduo B., and Nwaka F. (2016). Distribution of Antibiotic Resistant Bacteria from Abattoir Wastes and its Receiving Waters at Nkwo-ezzamgbo, Ebonyi State, Nigeria. World Journal of Medical Sciences. 13:242-250

28. Rousham E.K., and Unicomb M. A. (2018). Human, animal and environmental contributors to antibiotic resistance in lowresource settings: integrating behavioural, epidemiological and One Health approaches. Proceedings of the Royal Society B: Biological Sciences. 285(1876):20180332

29. Tian S. Wang Z. and Shang H. (2011). Study on the Self-purification of Juma River. Procedia Environmental Sciences. 11. 1328-1333.

30. Timilehin A. (2016). Occurrence of Antibiotic Resistant Bacteria in Faeces from Abattoir Waste, Processing Water and Products from Dutsin-Ma, Katsina State, Nigeria. Journal of bacteriology and Mycology. 3:1022
31. Van Boeckel TP, Gandra S and Ashok A. (2014). Global antibiotic consumption 2000 to 2010: an analysis of national pharmaceutical sales data. The Lancet. Infectious Diseases. 14(8):742-750.

32. Vougat N. R., Tomdieu T., Ziébe R., Foyet S, Moritz M., Vondou L., Schrunk D., Imerman P., Rumbeiha W. and Garabed R. (2017). Quality of veterinary pharmaceuticals and their use by pastoralists in the Far North Region of Cameroon. Pastoralism: Research, Policy and Practice $7: 6$

33. Watkinson AJ, Micalizzi GB, Bates JB, Costanzo SD (2007) Novel method for rapid assessment of antibiotic resistance in Escherichia coli isolates from environmental waters by use of a modified chromogenic agar. Applied and Environmental Microbiology. 7:2224-2229

34. Zanga A. D., Ajeagah G. A. and Ngassam P. (2018). Etats des Lieux, Qualite PhysicoChimiques et Biologiques des Effluents de L'abattoir Industriel de Yaounde. European Journal of Scientific Research. 148(4):412424.

35. Zhang X. X., Zhang T. and Fang H. H. (2009). Antibiotic resistance genes in water environment. Applied Microbiology Biotechnology. 82(3):397-414.Lekshmi et al., 2017;

36. Zébazé T. S. H., Njiné T., Kemka N., Nola M., Foto M. S., Monkiedje A., Niyitegeka D., SimeNgando T. and Jugnia L.B., (2005). Variations spatiales et temporelles de la richesse et l'abondance des rotifères (Brachiomidae et Trichocencidae) et des cladocères dans un petit lac artificiel eutrophe située en zone tropical. Revue des Sciences de l'eau 18(4): 485-505.

How to cite this article: Masse MT, Aloys RJS, Betbui BT et.al. Profile of antibiotic resistant bacteria isolated from slaughterhouse effluents of Etoudi-Yaounde and its receiving waterbody. Int J Health Sci Res. 2021; 11(4): 40-47. DOI: https://doi.org/10.52403/ijhsr.20210405 